\title{
The Influence of Risk Factors on The Emergence of Melasma on Female Street Sweeper in The
}

\section{Environmental Departement in Lhokseumawe 2017}

\author{
Devi Andriani ${ }^{1}$ \\ Magister in Public Health Science Program \\ Faculty of Public Health, University Of Sumatera Utara \\ Medan, Indonesia \\ deviandriani82@gmail.com
}

\author{
Gerry Silaban ${ }^{2}$, Rahayu Lubis ${ }^{3}$ \\ Department of occupational Health and Safety \\ Faculty of Public Health University of Sumatera Utara \\ Medan, Indonesia
}

\begin{abstract}
Melasma is a manifestation disorder of hypermelanosis. The incidence of melasma will result in a disruption of the facial skin as well as may cause a decrease in confidence in the sufferer, the incidence of melasma is still unknown, but the case is predominant in women than in men occurring up to $10 \%$ of cases. Melasma can affect all races especially the people living in the tropics and on the IV-VI skin types. In Indonesia the ratio of female and male cases is 24: 1 . One of those at risk for melasma is the woman in charge of sweeping the road. Women of street sweepers, they usually work from 7 am to noon and start working again at $2 \mathrm{pm}$ until the afternoon. The type of this research is analytic survey with cross sectional study design. The populations in this study were all female road sweeper workers, 49 were living in Kota Lhokseumawe with 49 samples taken from total population. The data were collected using questionnaire and examination by dermatologist and analyzed by chi square test at $95 \%$ confidence level. The results showed that $67.3 \%$ of women working for street sweepers in Lhokseumawe City have experienced Melasma. The chi square test showed that sun exposure and personal protective equipment use variables were significantly related to the incidence of melasma. In this case it is strongly recommended to the Environment Department in Lhokseumawe City to provide appropriate and monthly personal protective equipment to the women of the street sweeper workers, and conduct periodic checks every 3 months in relation to the work of female workers of street sweepers, socialization of the use of Personal Protective Equipment to prevent the occurrence of illness caused by work.
\end{abstract}

Keywords - Risk Factor; Melasma; Woman Street Sweeper

\section{INTRODUCTION}

Occupational disease is a medical-legal term. To label a disease, the causal relationship of the disease to working conditions that can lead to occupational disease. Which is one of the prerequisites for obtaining the standard rules in the relevant legislation. To prevent occupational diseases, it is imperative for a company to notify employees of working conditions, the potential effects of exposure to the condition, and safe ergonomic working principles. Training on workers should be done as well as practical training in the workplace [1].
Safety is one form of protection provided to the workforce, employers and assets of the company. Technical and technological control of the potential hazards of occupational accidents is the main thing in the effort of preventing accidents and improving safety and health performance in the company. Every accident is a loss and damage that always threatens the human soul and property both to the workforce, his family or businessman. So prevention is very important. Occupational health is implemented with the aim to improve the quality of life of the workforce, so that workers can feel and enjoy the results. Efforts in occupational health services in a business field play a very important role, because it involves human resources, productivity and welfare. Success in the realization of health work will have a positive impact in improving the company's productivity, income and also the welfare of the workforce This effort can only succeed if all parties are involved with a responsible awareness [2].

According to Suma'mur (2009) Occupational disease is one of the public health problems.Public health development efforts consisting of prevention, maintenance, treatment and rehabilitation are also applied to the prevention of occupational diseases to both formal and informal workers. Occupational diseases are caused by various factors in physical factor workers such as excessive heat pressures, high temperatures, moisture, light or the presence of a collision, this may also be caused by chemical factors, i.e. the use of chemicals or exposure to the above chemicals thresholds such as sodium, aluminium and the use of other chemicals, even this can also be caused by biological factors such as parasites, fungus exposure and so on [3].

One of the diseases that occur due to work is skin diseases such as melasma. Melasma is a manifestation disorder of hypermelanosis. The incidence of melasma leads to the occurrence of disorders of the skin while causing a decrease in confidence in the sufferer. Melasme is generally symmetrical macular-shaped macula that is not evenly brown to old, it comes from ultra violet rays in sunlight with a predilection of the cheeks, forehead, upper lip, nose and chin. Medically melasma is a health problem, and aesthetically can damage the beauty of women [4]. 
The incidence of melasma is still unknown, but dominant occurs in women than in men occurs in $10 \%$ of cases. Melasma can occur in all races, especially those living in the tropics and in IV-VI skin types. this is especially true in women, although it is also found in men. As has been known that melasma is more about people who have darker skin types, and it is often associated with people cultured Asia. In Indonesia the ratio of female and male cases is $24: 1$. this often occurs especially seen in women of childbearing age with a direct history of exposure to sunlight. most cases were found at the age of 30-44 years [5].

UV exposure (ultra violet) can stimulate melanocytes so the skin becomes darker. it is getting worse by the abundance of sun exposure in Indonesia. the presence of exposure to sunlight in Indonesia is often not balanced by public awareness in protecting skin health. This is often associated with the least knowledge of the individual it self [6].

Workers at risk for melasma are women with street sweepers, this is because they are routinely exposed to sunlight, and usually work from 7:00 am to 12:00 noon and will continue their work in the afternoon from $2 \mathrm{pm}$ to 4 $\mathrm{pm}$.The effects of skin disorders, such as redness, wrinkled skin, dryness and black spots appear in the face, and tend to lead to hyperpigmentation resulting in melasma. In general, road sweepers are women, and they only use headgear to avoid heat and mouthpieces to avoid dust, whereas faces and necks are sometimes not covered, thus exposed directly to sunlight [7].

The city of Lhokseumawe is one of the municipalities with a busy population, divided into 6 districts with a population of 2017 totalling 195,186 inhabitants, and through the Environment Agency has employed road sweepers. Based on the data of the Environment Agency in Lhokseumawe City, the number of sweepers was 106 officers accompanied by 11 heads of foremen who took responsibility in 6 sub-districts [7].

The results of the preliminary survey of female road sweeper workers have never been examined for health, Based on the results of direct observation of the researchers, of 49 female sweeper officers have found a number of 33 street sweeper women in general they have a complaint of brownish spots, there are patches of uneven blackness on the face similar to melasma clinical symptoms. Generally occurs in women with duration of work more than 2 years and with the age range of officers 30 years and over. they do not use facial cover when working, because the personal protective equipment especially masks are distributed from the cleanliness and city planning department once a year so that many are damaged and torn. The reason they give when they are working as street sweepers is only because of economic interests, they do not care about facial beauty this is due to the high cost of treatment to a dermatologist and assume that facial skin disorder is still not a symptom of disease that causes long pain and needs to be treated as soon as possible [7].

The etiology of melasma is still not known for sure. but there are several risk factors that are considered to play a role in the pathogenesis of melasma in road sweepers such as ultra violet rays, hormones, drugs, genetics, races, cosmetics and the rest are idiopathic. Characteristics of melasma patients are also believed to affect the pathogenesis of melasma, which in this case will be the basic data such as age, education, occupation, medication patterns, and complaints against accepted treatment [5].

Based on the situation, the researcher is interested to conduct a research about the effect of risk factors on the incidence of melasma on the female street sweeper workers at the Environment Office in Lhokseumawe City in 2017.

\section{RESEARCH METHODS}

This research uses analytic survey by using design of cross sectional study [8]. The population in this research was all women street sweepers. The total was 49 on street sweeper working women who work for the Environment Office in Lhokseumawe City that has worked more than 2 year. The technique of obtaining data used questionnaire that had been conducted a test of validity and reliability. The statistical analysis used univariate and bivariate analysis using Chi Square test. The study was conducted from October until December 2017 where is held in the working area of Environtment Office of Lhokseumawe City.

The data collection instrument used the questionnaire. Population taken in this research is street sweeper working women which amounted to 49 people. The sampling technique in this study used total sampling technique [8].

\section{RESULTS OF THE RESEARCH}

Based on the results of data processing of results obtained as follows:

\section{Analisis Univariate}

TABLE I

FREQUENCY DISTRIBUTION CHARACTERISTICS OF RESPONDENT BY AGE, WORK PERIOD AND KNOWLEDGE

\begin{tabular}{|c|c|c|}
\hline $\begin{array}{c}\text { Characteristics of } \\
\text { Respondents }\end{array}$ & $\mathbf{N}$ & $(\%)$ \\
\hline \multicolumn{3}{|l|}{ Age } \\
\hline $22-29$ years & 1 & 2.0 \\
\hline $30-37$ years & 6 & 12.2 \\
\hline $38-45$ years & 10 & 20.4 \\
\hline $46-55$ years & 32 & 65.3 \\
\hline Total & 49 & 100 \\
\hline \multicolumn{3}{|l|}{ Work Periode } \\
\hline $3-13$ years & 18 & 36.7 \\
\hline 14--24 years & 12 & 24.5 \\
\hline $25-35$ years & 19 & 38.7 \\
\hline Total & 49 & 100 \\
\hline \multicolumn{3}{|l|}{ Knowledge } \\
\hline Good & 18 & 36.7 \\
\hline Less & 31 & 63.3 \\
\hline Total & 49 & 100.0 \\
\hline
\end{tabular}

The results showed that in term of age, there are 49 respondents, the range of 22-29 years old is only 1 person (2.0\%), 30-37 years old are 6 respondents (12.2\%) 38-45 years old are 10 respondents (20.45\%) and 46-55 years old are 
32 persons $(65.3 \%)$. In other term is the respondents based on the working period, from 49 respondents, there are 18 persons (36.7\%) with 3-13 years of working period, 14-24 years are 12 persons $(24.5 \%)$ and $25-35$ years are 19 respondents $(38.7 \%)$ The last term is Knowledge, based on 49 respondents, there are 18 respondents $(36.7 \%)$ that have good knowledge and 31 respondents $(63.3 \%)$ have less knowledge.

TABLE II

FREQUENCY DISTRIBUTION OF RESPONDENT CHARACTERISTICS BASED ON MELASMA RISK FACTORS

\begin{tabular}{|c|c|c|}
\hline Risk Factor & $\mathbf{N}$ & $(\%)$ \\
\hline \multicolumn{3}{|l|}{ Sun Exposure } \\
\hline Yes & 32 & 65.3 \\
\hline No & 17 & 34.7 \\
\hline Total & 49 & 100.0 \\
\hline \multicolumn{3}{|c|}{ Personal Protective Equipment } \\
\hline Yes & 22 & 44.9 \\
\hline No & 27 & 55.1 \\
\hline Total & 49 & 100.0 \\
\hline \multicolumn{3}{|l|}{ Patient of Melasma } \\
\hline Yes & 33 & 67.3 \\
\hline No & 16 & 32.7 \\
\hline Total & 49 & 100.0 \\
\hline
\end{tabular}

The results showed that in terms of sun exposure, from 49 respondents, 32 respondents $(65.3 \%)$ are exposed by ultraviolet and other respondents (17 respondents (34.7\%)) are not experiencing the sun exposure.The use of Personal Protective Equipment (PPE), there 22 repondents (44.9\%) use PPE and 27 respondents (55.1\%) do not use PPE. The last term is the occurrence of melasma, based on 49 respondents of the research, 33 respondents $(67.3 \%)$ experiencing melasma and 16 respondents $(32.7 \%)$ are not experiencing melasma. The mayority of respondents are experiencing melasma 33 respondents $(67.3 \%)$.

\section{Analisis Bivariate}

TABLE III

THE RELATIONSHIP OF RISK FACTORS WITH MELASMA OCCURRENCE

\begin{tabular}{|c|c|c|c|c|c|c|c|}
\hline \multirow[t]{2}{*}{ Risk Factors } & \multicolumn{2}{|c|}{ Melasma } & \multicolumn{2}{|c|}{$\begin{array}{c}\text { Non- } \\
\text { Melasma }\end{array}$} & \multirow[t]{2}{*}{ Total } & \multirow[t]{2}{*}{$\%$} & \multirow[t]{2}{*}{$\begin{array}{c}p \\
\text { value }\end{array}$} \\
\hline & $\mathbf{N}$ & $\%$ & $\mathbf{N}$ & $\%$ & & & \\
\hline \multicolumn{8}{|l|}{$\begin{array}{l}\text { Ultra Violet } \\
\text { Ray Exposure }\end{array}$} \\
\hline Yes & 28 & 87.5 & 4 & 12.5 & 32 & 100.0 & 0.000 \\
\hline No & 5 & 29.4 & 12 & 70.6 & 17 & 100.0 & \\
\hline \multicolumn{8}{|l|}{$\begin{array}{l}\text { The use of } \\
\text { Personal } \\
\text { Protective } \\
\text { Equipment }\end{array}$} \\
\hline Yes & 18 & 81.8 & 4 & 18.2 & 22 & 100.0 & 0.047 \\
\hline No & 15 & 55.6 & 12 & 44.4 & 27 & 100.0 & \\
\hline
\end{tabular}

The results showed that sun exposure $(p=0,000)$, and the use of personal protective equipment use variables $(\mathrm{p}=0.047)$ were significantly related to the incidence of melasma.

\section{IV.DISCUSSION}

a. The correlation between risk factors of ultraviolet rays exposure and melasma occurrences at women street sweepers in Lhokseumawe City.

The result of statistical test used chi square test was obtained $\mathrm{P}$ value $=0,000$. It meant that there was a significant relationship between risk factor of ultraviolet ray exposure and melasma occurrence at women street sweeper in Lhokseumawe City in 2017.

The result of the research showed that the relationship between risk factor of ultraviolet ray exposure and melasma occurrence at the women street sweepers in Lhokseumawe City were obtained $28(87,5 \%)$ melasma occurrence in Women employees which were caused by ultraviolet ray exposure. The respondents exposed to sunlight had a risk of $12.727 \approx 13$ times more had risk melasma than the respondents that were not exposed. It was published to Fitzpatrick that there were different number of melanocytes between different areas in each individual body. In areas that were often hit by sun exposure such as in the face, there were about 2,000 or more melanocytes persquare millimeter, whereas in other area about 1,000 per square millimeter, melanocyte activity increased, the process of melanogenesis was encouraged it caused hyperpigmentation.

Chloasma, or melasma, is a pigmentary disorder that typically appears on the face, forehead, cheeks and chin. It occurs most frequently in women with Fitzpatrick skin type III or higher, especially those of Asian origin, Timur Tengah, Amerika Selatan, Afrika, dan sub kontinen India. Asian is associated with negative psychological and emotional effects [9]. Factors that play a role in the pathogenesis of melasma include exposure to UV radiation [7] [10]

UV light is another very important factor, whose role has been appointed and proven by numerous studies and case reports. UV-B, UV-A as well as visible light are all capable of stimulating melanogenesis. The above are not considered to be able to cause melasma without genetic predisposition or hormonal changes, but are thought to be very important in triggering the disease, if the background exists [11]. The survey results in Tunisia looked for factors that affect the incidence of melasma, UV light exposure is a trigger factor in $51 \%$ of patients and a factor that aggravates $84 \%$ [12].

Tzouveka (2014) The exact cause of melasma remains unknown, although many factors have been implicated in the pathogenesis of this disease with $40 \%$ of patients having at least one relative to the disease. Factors that affect and trigger the onset of melisma include exposure to UV radiation, darker skin colors [13].

b. The correlation of risk factor for the use of personal protective equipment with the melasma occurrence at the women street sweeper in Lhokseumawe City in 2017. 
The result of statistical test used chi square was obtained $\mathrm{P}$ value $=0,047$. It meant there is a significant correlation between risk factor of the use of personal protective equipment and melasma occurrence at the women street sweeper in Lhokseumawe City in 2017.

The research results showed that the use of personal protective equipment with the melasma occurrence at the women street sweeper in Lhokseumawe were found that there were 18 people $(81.8 \%)$ melasma that were occured atwomen employees that was caused by the use of personal protective equipment. Melasma affects many patients whose occupations were often exposed to sunlight without wearing personal protective equipment or without sufficient medicament. As the basic data that influenced the frequency of the melasma occurrence the patients such as age, gender, type of work, and level of education.

Occupational health protection is Personal Protective Equipment (PPE). According to OSHA, or the Occupational Safety and health Administration, Personal protective equipment or tool is a tool used to protect workers from injury or disease that causes by contact with hazards (Hazard) in the workplace. Personal protective equipment is tools capable of providing protection against accident hazards. PPE is the completeness that must be used when working in accordance with the danger and work risk to maintain the safety and health of the workers themselves and the community [14].

\section{CONCLUSIONS}

Based on the research on the risk factors with the melasma occurrence, there are 33 people $(67.3 \%)$ that is hit melasma and 16 people $(32.7 \%)$ do not melasma. The majority of respondents become the patients of melasma 33 people $(67.3 \%)$.

Thus the sun exposure variable with melasma occurrence that there is a significant. Chi square test obtained $\mathrm{p}$ value $=$ 0,000 at $95 \%$ confidence level. Variable the use of personal protective equipment with melasma occurrence the result of statistical analysis show there is correlation of the use of personal protective equipment with melasma occurrence in the respondents obtained as many as 18 respondents $(81.8 \%)$. Chi square test results obtained that the value of $p=0.047$ at $95 \%$ confidence level. Meaning that there is a significant relationship between of the use of personal protective equipment with melasma occurrence.

\section{ACKNOWLEDGMENT}

The researcher would like to show her gratitude to Dr. Ir. Gerry Silaban, M. Kes, Senior Lecturer of Faculty of Public Health of University of Sumatera Utara for the great assistance and wisdom during the course of this research. The researcher also thank dr. Rahayu lubis, M. Kes, Ph. D for the advice, guidance, and motivation that he gives to the researcher to finish this research.
Finally, she would like to thank everybody who were important to the successful realization of journal. This study is far from perfect, but it is expected that it will be useful not only for the researcher, but also for the readers. For this reason, constructive thoughtfull suggestion and critics are welcomed.

\section{REFERENCES}

[1] Marek, K., and Bugajska, J. Handbook of Occupational Safety and Health Editor Koradecka D. New York : CRC Press, 2010.

[2] Tarwaka, Industry ergonomis: Applied and bases ergonomics knowledge in workplace, Harapan Press: Surakarta-Indonesia, 2013.

[3] P.K. Suma'mur, Occupational health and safety and Company Hygiene: Sagung Seto, Jakarta, 2009.

[4] Kabulrachman. Pigment Disorder. In: M. Harahap, (Editor). Dermatology, Hipokrates, Jakarta, 2015.

[5] Soepardiman, L. Pigment Disorder. In: Menaldi S.W. S., Bramono K., Indriatmi W (Editor). Dermatology, Vol 7, FKUI, Jakarta, 2015.

[6] Fitzpatrick, T.B., Klaus, W., Johnson, R.A., Polano, M.K., Suurmond, D. Melasma. in: Colour Atlas And Synopsis Of Clinical Dermatology : Common And Serious Disease. Vol 6. New York : Mcgraw-Hill, 2005.

[7] Department of the Environment, Lhokseumawe in figures 2014, Lhokseumawe: Department of the Environment, 2014.

[8] Muhammad, I., 2015. Guidelines for the Preparation of Scientific Writing Field of Health Using Scientific Method. Cita Pustaka Media Perintis, Bandung, 2015

[9] Goodheart, H. P. Diagnosis Fotografik dan Penatalaksanaan Penyakit Kulit, Editor B.U. Pendit. Vol 3. EGC, Jakarta, 2013.

[10] Guinot C, Cheffai S, Latreille J, Dhaoui MA, Youssef S. Aggravating factors for melasma, a prospective study in 197 Tunisian patients, Journal Eur Acad Dermatol Venereol, 2010.

[11] Jadotte YT, Schwartz RA . Melasma: insights and perspectives. Journal Acta Dermatovenerol Croat, 2010.

[12] Tzouveka, E. Epidemiology and Risk Factors of Melasma. Journal of Pigmentary Disorders, 2014.

[13] Alamsyah, D. Basic Pillar of Public Health Sciences. Nuha Medika, Yogyakarta, 2013. 